\title{
PENGARUH HORTICULTURE THERAPY TERHADAP TINGKAT AGRESI NARAPIDANA: SEBUAH ANALISA RASCH MODEL
}

\author{
Tim Yayasan Inisiatif Indonesia Biru Lestari (Waibi) \\ info.ecoblue@gmail.com
}

Kata Kunci:

narapidana, berkebun, RASCH model,

agresivitas

Key words:

prisoners, farming, RASCH model, agression

\begin{abstract}
Abstrak
Penelitian ini bertujuan untuk mengukur berapa dan bagaimana pengaruh horticulture therapy terhadap agresivitas narapidana dengan menggunakan pendekatan Rasch Model. Disamping itu juga menyajikan profil antara person (sampel) dengan instrument pengukuran (aggression scale) yang disajikan dalam satu table yang disebut Person-Item Map. Sampel penelitian ini sebanyak 32 nara pidana yang sudah mengikuti program horticulture therapy di LapasJakarta dan Banten dengan menggunakan teknik purposive sampling. Meskipun jumlah sampel relative sedikit, namun hasil analisis data menunjukkan bahwa modelnya fit/cocok/sesuai, dengan nilai RMSEA (Root Mean Square Error of Approximation) sebesar 0,000 dimana ini nilainya dibawah probability value of $<=0,05$. Artinya, teori yang diuji adalah benar bahwa agresivitas seseorang merupakan variable yang mempengaruhi kecenderungan berbuat criminal. Hasil analisis $R$-Square pengaruh horticulture therapy terhadap agresivitas menunjukkan sebesar $R^{2}=0,298$ dengan $p$ value $<0,05$. Hal ini berarti bahwa horticulture therapy memiliki kontribusi terhadap agresivitas narapidana sebesar 29,8\% (sekitar 30\%). Dengan kata lain, dapat dinyatakan bahwa aggression of the prisons is accounted for by horticulture therapy as much as 30\%.
\end{abstract}

\begin{abstract}
The purpose of this study is to measure the contribution of horticulture therapy to the level of aggression of the prisoners in a few prisons. The Rasch model approach was used in this study. Using Rasch model is to analyze individual as well as group level of aggression of prisoners based on their demographics and backgrounds. Using the Rasch model the results of the analyses can be presented in two dimension mapping or variables maps. The methods of this study were by administering questionnaires for demographic and their backgrounds, observations for recording the convicts' behavior and opinions regarding the horticulture therapy program, and administering aggression instruments which are consist of physical, verbal, anger, and hostility dimensions. Sample was 32 convicts from three different prisons in the Jakarta areas: Cipinang, Tangerang, and Serang prisons. The results of the analysis of $R$-Square influence of horticulture therapy against aggressive show of $R 2=0.298$ with $p$ value $<0.05$. This means that the horticulture therapy contributes to the aggressiveness of prisoners amounted to $29.8 \%$ (approximately 30\%). In other words, can be stated that: the aggression of the Prisons is accounted for by horticulture therapy as much as $30 \%$.
\end{abstract}

